\title{
Toe die vierde Taalkommissie in sy spore gestuit is
}

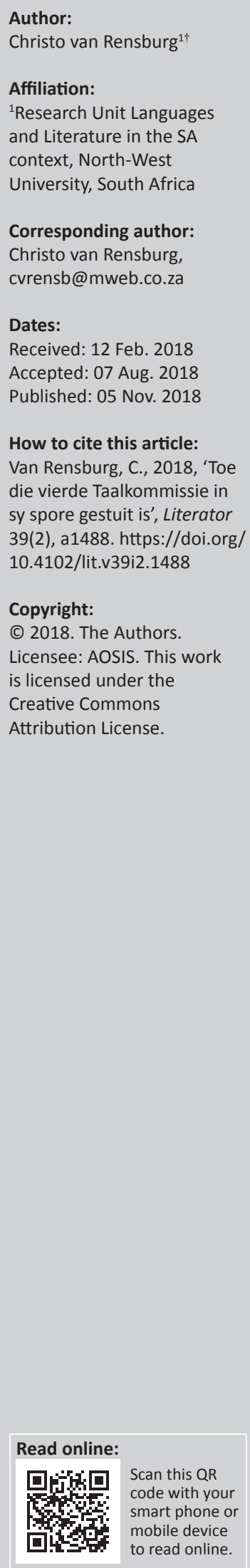

When a language commission was stopped in its tracks. In the course of the standardisation of Afrikaans, the first two editions of the Afrikaanse woordelijs en spelreëls, published in 1917 and 1918, were heavily inundated with Dutch words. During that time Afrikaans was a well-known spoken language, and since 1860 it was sporadically written as well, without any uniformity, however. In the third edition of the Afrikaanse woordelys en spelreëls of 1921, the third spelling commission made some telling changes to the first editions, and a good part of the Dutch content was replaced with Afrikaans words, and spelling rules were altered for the spelling of Afrikaans as well. The fourth edition of this publication tried to follow suit, but contrary to expectations, was subjected to some changes by a conference chaired by the minister of education in 1930. This conference requested for the content of this edition to be Dutchified in some important ways, shortly before its publication in 1931. These changes didn't satisfy the delegates of a second conference, held in 1932. An unheard-of decision was subsequently taken: corrections were published in 1932 to accompany the fourth Afrikaanse woordelys en spelreëls. This decision wasn't very effective and resulted in much uncertainty about the spelling of Afrikaans until the publication of the next Afrikaanse woordelys en spelreëls, of 1937.

\section{Die vooruitsig vir die Taalkommissie vir AWS4}

Bepaalde omstandighede het daaraan meegewerk dat die Taalkommissie (TK) wat die vierde Woordelys en Spelreëls (AWS) van 1921-1931 saamgestel het, moes toegekyk het hoe die inhoud van AWS4 (Boshoff, Bosman, Le Roux et al. 1931) met sy voltooiing, en kort na sy verskyning, gewysig is (vergelyk ook Van Rensburg 2017a en 2017b). Daardie stukkie geskiedenis volg hierna.

Afrikaanssprekendes het met groot verwagting uitgesien na die spelleiding wat AWS4 vir hulle sou gee, merk Kapp (2009:111) op. Sy voorganger, AWS3 (Bosman, Le Roux, Malherbe et al. 1921), het reeds in 1921 verskyn. T.H. le Roux het in sy 'Voorwoord' tot AWS1 (Le Roux, Malherbe \& Smith 1917) (AWS1:III) 'n AWS in die vooruitsig gestel wat by die Afrikaanse aard van die spelling van die 'taalpioniers' van die Genootskap van Regte Afrikaners (hierna die GRA) van 1875 kon aansluit. Dié 'taalpioniers' het, volgens die leier van dié beweging, S.J. du Toit, die 'Hollandsgetinte Afrikaans van deftige sprekers' onderskei van die Afrikaans wat die GRA wou reglementeer (vgl. Steyn 2014:23).

AWS3 het aan daardie verwagting wat Le Roux gehad het, begin voldoen, deurdat hulle nie genoeë geneem het met die groot aantal Nederlandse woorde wat in die eerste twee Afrikaanse woordelyste en spelreëls opgeneem is nie, waaronder aubade (om iemand te groet), femelaar, freule (adellike jonkvrou) en faljiet (bankrot). (Vgl. Odendaal 2016:267 vir nog sulke inskrywings in AWS1.) (In aansluiting by die praktyk wat in 1937 begin is met die verskyning van party uitgawes van AWS5 [Boshoff, Bosman, Hiemstra et al. 1937], word die kommissies wat die AWS'e saamgestel het hierna Taalkommissies [TK's] genoem.)

Die TK wat AWS4 saamgestel het, het met dié praktyk van verafrikaansing voortgegaan, en telkens die vraag gevra: Hoe Nederlands mag die inskrywings van AWS4 wees, en hoe moet daardie Nederlands geregverdig word indien Afrikaans meer soos Nederlands moes lyk? Die Eerste Spellingkonferensie wat in Pretoria op 27-28 Augustus 1930 gehou is (sien verder aan), het ook probeer om 'n antwoord op dié vraag te verskaf.

AWS4 se verhaal het begin met die verskyning van AWS3 in 1921 waarna die Suid-Afrikaanse Akademie vir Taal, Lettere en Kuns (tans die Suid-Afrikaanse Akademie vir Wetenskap en Kuns), die Spellingkommissie aangewys het vir die samestelling van die vierde AWS.

Note: Die outeur is tydens die voorfinale fase van die redaksionele proses oorlede. Die redaksie het besluit om te volstaan met die teks soos hy dit ingedien het - met die laaste wysigings wat hy self aangebring het. Slegs minimale en noodsaaklike verdere wysigings is deur die redaksie aan die teks aangebring.

$\dagger, 1938-2018$. 


\section{Die kontinuïteit van die Taalkommissie}

Die Akademie het T.H. le Roux, D.F. Malherbe, D.B. Bosman en J.J. Smith, dieselfde TK wat vir AWS3 vanaf 1918 tot 1921 verantwoordelik was, herbenoem as lede van die AWS4-TK, en het ook vir S.P.E. Boshoff as 'n nuwe lid aangewys. Die TK het vir D.F. Malherbe as voorsitter gekies. Op 28 Mei 1926 het Smith as Taalkommissielid bedank (NALN, Malherbe-korrespondensie), en sy naam kom nie op die buiteblad van herdrukke van AWS4 voor nie.

Vier van hierdie vyf lede van die AWS4-TK, Le Roux, Malherbe, Bosman en Boshoff, maar nie Smith nie, het hulle duidelik verbind tot die voortsetting van die verafrikaansing waarmee AWS3 'n begin gemaak het.

Smith se siening oor die verskrifteliking van Afrikaans het nie goed by die gedagtes van die res van die Taalkommissielede daaroor ingeskakel nie. Die kiem van die onenigheid tussen die lede van die TK het dáár gelê. Hy wou die vereenvoudigde Hollandse Spelreëls (VHS) volg, en het daarnaas ook sy eie spelreëls voorgestaan wat verskil het van die spelreëls van die TK's waarop hy gedien het, wat ook nader aan Nederlands gestaan het (Kapp 2009:123) en wat selfs in enkele publikasies gebruik is (Steyn 2014:215). Op 6 Julie 1918 het Smith die Akademiesekretaris meegedeel dat Die Burger-leeskring op Stellenbosch (wat onder sy invloed gestaan het), 'die Akademiespelling [volg], hoewel ons hier en daar kleine wijsiginkies vir onsself veroorloof'. Met 'wijsiginkies' het hy sy volgehoue gebruik van Nederlandse woorde in geskrewe Afrikaans probeer verdoesel, waarvan Steyn (2014:215) en Le Roux (1968a:173) voorbeelde gee, waar onder: Anglicisme, etymologie, producent, medicyne en speciaal.

Smith kon nie daarmee vrede maak dat die meerderheid van die TK-lede nie tot sy sienings oor die vernederlandsing van geskrewe Afrikaans oorgehaal kon word nie. Dié situasie het nie verander toe hy in 1926 hoofredakteur van die Woordeboek van die Afrikaanse Taal (WAT) geword het, en sy sienings vanuit dáárdie posisie wou laat geld nie. Die WAT het nie van die TK samewerking gekry nie, het Smith sy lot oor sy alleenstryd na buite bekla, soos blyk uit F.S. Malan se mededeling aan die Akademiejaarvergadering van 1927. Smith sou vir hom gesê het 'dat hy (prof. Smith) geen ondersteuning ontvang van die Spellingkommissie nie' (TWK 6[1]:106, notule van die 1927 Jaarvergadering). F.S. Malan het hom by Smith ingelaat: Hy wou sien dat Afrikaans 'so na bly staan aan Nederlands, as wat maar moontlik is' (TWK 6[1]:106, Akademiejaarvergadering 1927). Daar is ook vir Smith in die bresse getree oor die afwykende spelwyse wat hy in die WAT wou volg. Dr N.M. Hoogenhout het op 'n Akademievergadering gesê hy 'is dit moeg' daarvoor dat hierdie Woordeboekkwessie telkens opgehaal word: dit sou 'n refleksie kon werp op die goeie naam van die hoofopsteller, prof. Smith (TWK 6[2] Des. 1927). Smith het mettertyd 'n invloedryke ondersteunerskorps om hom opgebou. Die openlike steun aan Smith was tekenend van die polarisasie wat daar tussen Smith en die AWS4-TK ontwikkel het. Sienings dat Afrikaans so na as moontlik aan Nederlands moes staan, het lynreg verskil van die uitgangspunte wat die TK-lede Le Roux, Malherbe, Bosman en Boshoff daarop nagehou het.

In F.S. Malan het Smith 'n belangrike vennoot gehad in sy teenkanting teen die voortgesette verafrikaansing van AWS4. Hy het grootgeword binne 'n liberale Kaapse tradisie (Kallaway 1974) en was tussen 1895 en 1908 redakteur van die Nederlandstalige tydskrif Ons Land. In 1927, die jaar waarin die Akademievergadering plaasgevind het waartydens hy vir Smith probeer ondersteun het, is hy tot die Senaat verkies. Hy het steeds 'n belangrike rol in Akademiesake gespeel, en is as voorsitter van die Akademie verkies tussen 1934 en 1936.

Die konflik tussen die voorstaanders van Afrikaans en dié van Nederlands oor inskrywings in AWS4 kan gedeeltelik verklaar word aan die hand van 'n stelling van Ponelis: 'Daar is en was 'n neiging in die Afrikaanse historiese taalkunde om die kontinuitteit tussen Afrikaans en Nederlands te oordryf' (Ponelis 1999:24). Die Nederlandse inhoud van AWS1, in die Vereenvoudigde Nederlandse Spelling (VHS en later VNS-spelling genoem), kan nie teruggevoer word na 'n voorkeur daarvoor van die Afrikaanse 'spraakmakende gemeente' nie (gemeente in die betekenis van publiek), waarop Le Roux hom dikwels beroep het oor spellingkwessies (vgl. Le Roux 1968b). AWS1 en 2 se Afrikaans was nie die Afrikaans van die Afrikaanse gemeenskap van daardie tyd nie. Reël 11 van AWS1 stel dit uitdruklik dat Nederlands in bepaalde gevalle met voorbedagte rade verkies is bo Afrikaans:

Waar d na 1, n, r in Hollands uitgespreek, maar in Afrikaans gewoonlik aan die voorafgaande klank gelijk gemaak word, daar word d in die Afrikaanse spelling tog behou: kelder, helder; kinders, wonder; worde (naas word); perde (mv. van perd).

Met min uitsonderings kan die Nederlandse woorde in AWS1 en 2 in die Nederlandse woordeboeke van Elffers en Viljoen (1908) en Van Rijn (1908) teruggevind word, woordeboeke wat 'voor Zuid-Afrika' volgens die VHSspelling saamgestel is (Elffers \& Viljoen 1908: titelblad en voorwerk). Die TK van AWS1 was verbind om dié VHSspelling te volg (Van Rensburg 2017c). Was hulle plundering van hierdie werke dalk te begrype omdat hierdie woordeboeke alreeds gespel het soos dit vir AWS1 neergelê is om te doen in grondbeginsel [d]? Die uiteindelike gevolg daarvan? 'n Tendens wat 'n 'geleidelike losmaak van die Nederlands georiënteerde spelwyse in die rigting van verafrikaansing' was, het Eksteen $(1985: 171,180)$ opgemerk.

\section{Die historiese basis van geskrewe Afrikaans}

Die Taalkommissielede en ander belangstellendes wat $A W S^{\prime}$ e met Afrikaanse inhoude in die vooruitsig gestel het, kon hulle verwagtings gegrond het op waarnemings (soos wat Mansveld 1848:135 gemaak het) dat Afrikaans teen die 
begin van die twintigste eeu herken kon word as 'n afsonderlike taal wat dwarsoor Suid-Afrika, 'van de Kaap tot de Limpopo', gepraat is. Giliomee (2003:213) merk ook op: 'by 1875 Afrikaans ... was spoken across most of the present South Africa'. In die negentiende eeu is Afrikaans in tallose persoonlike briewe geskryf (waarvan Raidt 1986 en De Klerk 1994 voorbeelde gee), en in korrespondensie aan koerante aangewend (Van Rensburg \& Combrink 1984).

Afrikaans het al vroeg in publikasies verskyn. In 1868, en moontlik selfs vroeër, kon dit in die Kaap gelees word (Davids 2011:90 e.v.). Aan die Oosgrens het Meurant dit al in 1860 geskryf (Nienaber 1940; 1968), naas ander skrywers, en in Genadendal is Afrikaans van 1859 afgedruk (Belcher 1987:29). Van 1875 af is Afrikaans in die Paarl in die omvangrykste verskriftelikingsproses van die twintigste eeu in Suid-Afrika geskryf (vgl. Steyn 2014:23 e.v.). Die Afrikaans wat dáár geskryf is, het 'n doelbewuste standaardiseringspoging in die oog gehad (Du Toit 1897), wat aangehelp is deur die publikasie van 81000 boeke tussen 1878 en 1898 (Steyn 2014:23).

S.J. du Toit (1880) het daarop gewys dat die taal wat Meurant teen 1860 gebruik het om die Oosgrensboere se gesprekke na te maak, Afrikaans was, en hy haal die volgende sin van Meurant (met Klaas Waarsegger aan die woord) uit 'n langer gedeelte ter illustrasie aan:

$\mathrm{Al}$ de gelt van landsinkomste gaat in een kas aan de Kaap. Hulle fermors de gelt, en leen nog bovenop, en ons moet toesien en rente betaal. (bl. 4-5)

Du Toit kon egter nie nalaat om op Meurant se Nederlands te wys wat in sy Afrikaans deurgeslaan het nie. In 1880, toe die GRA-spelling al goed op dreef was, het hy aangetoon dat Meurant se Afrikaans met enkele aanpassings GRAAfrikaans kon wees, maar toon tog nóg gevalle van verafrikaansings aan wat Meurant kon aangebring het: 'Di Lidwoord de moet wees $d i^{\prime}$, en verder moet 'di ch ... weg', ten gunste van die spelling met $k$. Hy het ook daarop gewys dat Meurant nie $z$ nie, maar $s$ moes skryf, asook mar en nie maar nie, goeie en nie goede nie, en hê en nie hebbe nie.

Afrikaans, ook geskrewe Afrikaans, het baie name gehad, veral in kombinasie met Hollands of Nederlands. Langenhoven (Die Brandwag 01 April 1913:666) neem 'n duidelike standpunt daaroor in, wat gebruikers van sulke samestellings heel waarskynlik tot nadenke sou gestem het. Langenhoven se regverdiging vir sy kritiek op sulke name was dat dit 'Afrikaans dadelik in 'n inferieure posiesie [plaas] terwijl dit hom van sij selfstandigheid beroof'.

\section{Die politieke omgewing tydens die samestelling van AWS4 (1921-1931)}

In die Grondwet van die Unieregering van 1910 is gelyke taalregte vir die sprekers van Nederlands en Engels gewaarborg (artikel 137). Daarvan het nie veel in die praktyk tereg gekom nie (vgl. Steyn 1987:72 e.v.). Terwyl Nederlands afgeskeep is, waar sou Afrikaans ooit gehoor kon word?

Toe gebeur dit dat die stemgeregtigdes in 1924 in Suid-Afrika 'n nuwe regering, die sogenaamde Paktregering, aan bewind geplaas het (Steyn 2014:205 e.v.). Dit het voordele vir Afrikaanssprekendes ingehou. Nou kon hulle darem probeer om Afrikaans ook te gebruik, skoorvoetend onder die verskoning van Nederlands. Dit het tot 'n groeiende positiwiteit onder Afrikaanssprekendes oor hulle taal en hulle kultuurgoedere gelei. Vir Afrikaans en die TK van AWS4 het hierdie beklemtoning van gelyke taalregte positiewe vergesigte ingehou, anders as onder die vorige regering van Smuts (Steyn 2015b:49).

Die ontwikkeling en kultivering van Afrikaans het toenemend aandag gekry, nie net deur die TK van die Akademie met die opstel van $A W S^{\prime}$ e nie, maar ook deur nuwe instellings soos die vertaalkantoor wat die regering ingestel het, en wat onafhanklik van die Akademie se TK gefunksioneer het. Afrikaanse kultuurverenigings het ook ontluik (Liebenberg 1968:364), waarmee die uitbouing van die beeld van Afrikaans gepaardgegaan het. Daar het mettertyd 'n band ontstaan tussen opeenvolgende proAfrikaanse Regerings en Afrikaanse instellings wat lateraan al hoe hegter geraak het, en tot gevolg gehad het dat die sterkerwordende nasionalisme wat deur Afrikaanssprekende politici gepredik is tot bevoordeling en eksklusiewe bevordering van Standaardafrikaans, gelei het. Dit het op die lange duur Afrikaans se bestaan in gedrang gebring. 'Afrikanernasionalisme het Afrikaans gemitologiseer as voertuig van 'n wit nasionalisme, het $H$. du Plessis opgemerk' (Du Plessis 2001:70). Dit is opmerklik dat Engelenburg in 1911 al benadruk het 'dat dit nie wenslik was nie, en in sekere opsig gevaarlik sou wees', vir die Akademie om hulp van die staat te vra (Brink 2015:287). Hy was bang vir regeringsinvloed op die Akademie. Later in die Akademie se bestaan sou hierdie vermyding van regeringsinvloed hom miskien goed te pas gekom het.

En die stand van Afrikaans gedurende die twintigerjare? Dit was in hierdie periode waartydens AWS4 saamgestel is, dat die dominansie van Engels op die openbare terrein getemper is, en Afrikaans mede-ampstaalstatus verwerf het (Giliomee 2009:376). Die WAT is begin, asook kleiner Afrikaanse woordeboeke, en verskeie grammatikas en skoolboeke het verskyn (vgl. Steyn 2014:195 e.v.), en meer en meer romans en ander prosawerke. Onder hulle het die Akademie Hans die skipper van D.F. Malherbe, Kees van die Kalaharie van G.C. en S.B. Hobson en J. van Bruggen se Ampie die meisiekind uitgesonder vir bekroning (TWK 9[2] Des 1930:86). Die Akademie se naam is ook na die Suid-Afrikaanse Akademie vir Taal, Lettere en Kuns toe verafrikaans. Dit lyk of die Paktregering ten minste mede-aandadig daaraan was om 'n klimaat te skep vir Afrikaanssprekendes om hulle taal met meer vrymoedigheid te gebruik en dit te ontwikkel. Met AWS4 is daar ook in hierdie periode goeie vordering gemaak, 
volgens die sesmaandelikse verslae aan die Akademie na elke TK-vergadering.

Die 'Voorwoord' van AWS4 (van 1930) reflekteer iets van Afrikaans se groeiende status en van Afrikaanssprekendes se groterwordende rol in die Suid-Afrika van die derde dekade van die twintigste eeu. Die saambindende rol wat Afrikaans in die Afrikaanssprekendes se identiteitsvorming gespeel het, kan in die gebruik van volkstaal in dieselfde betekenis as Afrikaans gesien word. In AWS4 kom daar 29 samestellings met volk(s)- as eerste lid voor, wat 'n aanduiding van die bewuswording van 'n volksgevoel onder Afrikaanssprekendes kan wees. Van dié inskrywings is 16 abstrakte naamwoorde, soos volksaak en volksaard. Steyn (2015:10) merk op dat die gebruik van volk sedertdien afgeneem het, en dat die ongunstige gevoelswaarde wat daaraan gekoppel is, moontlik aan 'vroeëre misbruik deur politici en ander toespraakmakers' toegeskryf kan word. In 'n kort briefie van dr. H.F. Verwoerd aan D.F. Malherbe (NALN, D.F. Malherbe-versameling, 12 September 1958), gebruik Verwoerd volksplig wat dié waarneming bevestig. Die aantal inskrywings van volk- in AWS11, in vergelyking met AWS4, klop ook met Steyn se opmerking: Dáár kom net 14 inskrywings met volk- as 'n samestellende lid voor, maar in 'n totaal ander betekenisveld. Slegs een inskrywing, volksaard, (en miskien volksplanting) is emotiewe selfstandige naamwoorde.

Gesien hierdie omstandighede wat Afrikaans ondersteun het in die verplasing van Nederlands, kan verwag word dat die ernstige verafrikaansing van die TK aan AWS4 wye waardering sou geniet.

\section{Verafrikaansing of nie?}

Die erns waarmee die AWS4-TK hulle verafrikaansingsvoorneme bejeën het, blyk daaruit dat hulle verafrikaansing nie minder as ses keer in die Voorwoord gebruik het nie. Hulle produk, AWS 4, het dit op die ou einde nie geillustreer nie: Vergelyk die inskrywings met au wat die TK van AWS3 in 1921 reeds geskrap het, en wat in AWS4 weer heropgeneem is, soos aubade, aureool, auditeur, auteur, authentiek, auto, autokraties, autorisasie en autoriteit, naas Afrikaanse woorde wat met die aanvangs-ou strook. Dit het glad nie met hulle verafrikaansingsvoornemens gestrook nie.

Die AWS4-TK se verduideliking? Ons het 'meer dubbelspellinge aangegee as wat in ons oorspronklike bedoeling gelê het' (AWS4:VII), verskoon die AWS 4-TK hom. Hoekom het hulle so teruggekrabbel na Nederlandse inskrywings toe?

Die geskiedenis van AWS4 wentel om die verafrikaansing van die inhoud daarvan, en die reaksies wat dit ontlok het. Ná die verskyning van AWS1 in 1917, en AWS2 in 1918 (Le Roux, Malherbe \& Smith 1918) wat eintlik net 'n herdruk van AWS1 was, moes elke TK daarna op die een of ander manier die AWS1-erflating hanteer wat Afrikaans soos Nederlands laat lyk het (Uys 1983), asook die toenemende verwikkeldheid van die implikasies van daardie vroeë besluite oor vernederlandsing (vgl. Van Rensburg 2017c vir die redes vir die vernederlandsing van AWS1).

Die faksie in die Akademie, wat verafrikaansing teengestaan het, se pro-Nederlandse houding was nog sterk, al het hulle vermoedelik grootliks uit Afrikaanssprekendes bestaan, waarvan Preller 'n goeie voorbeeld was (Steyn 1987:207). Daarbenewens het teenstand wat met die landspolitiek te make gehad het, Afrikaanssprekendes begin polariseer. Engels was die taal van die ondersteuning aan Engeland in die 1930's toe oorlogswolke begin opbou het en daar sprake was dat Suid-Afrika die Britse oorlogspoging in Europa gaan ondersteun (Giliomee 2003:428 e.v.). Voorstelle tot spellinghervorming wat in 1926 gemaak is (Steyn 1987:209), het roeringe oor die Afrikaanse spelling in die pers veroorsaak, en het die grense van matige verafrikaansing miskien oorskry. Van die voorstelle het die opheffing van $\mathrm{f} / \mathrm{v}$ en ei/y-onderskeiding gepropageer sodat spellings soos fryhyt moontlik sal wees. Geslagte skoolkinders sou hierdie wysiging verwelkom het, maar die voorstelle is nooit aangeneem nie. Hulle is selfs as uitdagend ervaar vir die behoud van die verbintenisse tussen Afrikaans en Nederland, het Ons Vaderland op 19/12/1926 berig. Die voorstelle het wye publisiteit gekry, en sou 'n steen des aanstoots vir behoudende Nederlandsrespekterende Afrikaanssprekendes gewees het.

Daar is meermale oor spellinggeskille in die dagblaaie berig, soos wat die onderstaande spotprent in Die Burger van 25 Oktober 1930 ook die aandag op die Akademie (Malherbe) en die Smith-kamp se spellingonderonsies gevestig het.

Malherbe, die Taalkommissievoorsitter, het die spelling ondersoek van vreemde woorde (waaronder Nederlandse woorde geval het), die saak wat in die middelpunt van die dispuut gestaan het, in 'n bydrae in die Oktoberuitgawe van die TWK van 1930. Sy bevinding was eenvoudig: Vreemde woorde (soos Nederlands ether) hoort nie in die AWS nie. Smith-hulle het hulle opinies oor die noodsaaklikheid van vreemde woorde in die AWS egter nie deur Malherbe se ondersoek laat wysig nie. Malherbe het met sy publikasie ook geen onduidelikheid gelaat waar hy gestaan het in die spellingstryd nie.

Op die spellingfront het talle belanghebbendes iets te sê gehad oor hoe daar Afrikaans gespel moes word. Die kantoor

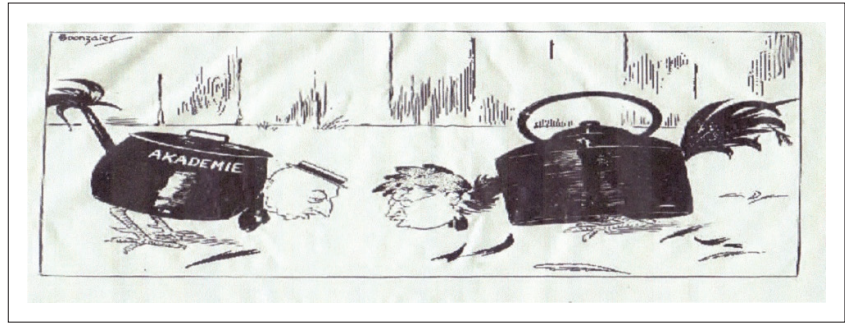

Bron: Die Burger, 1930, 'Titel onbeskikbaar', Die Burger, 25 Oktober, n.p FIGUUR 1: Spotprent 
van die WAT wat aan die Universiteit van Stellenbosch gevestig is, het dié universiteit ook ' $n$ belang gegee in die woelinge op die taalfront.

Daar is ook nog die Bybelvertalers wat hulle meermale in onmoontlike situasies bevind het. Vir dié TK het die Bybelvertalers se Afrikaans te naby aan Nederlands gestaan. Hulle was ook haaks met mense soos Preller vir wie hulle Bybelafrikaans weer te ver van Nederlands af gestaan het. Preller het in 1927 die Bybelafrikaans (van die proefvertalings) as 'ongeskik, rudimentêr en gewestelik' gekritiseer (Steyn 1987:208).

Die verafrikaansings het nie altyd in die Bybelvertalers se smaak geval nie. Hulle het Exodus soos in Nederlands gespel, terwyl die TK's in sulke gevalle duidelik voorkeur aan die Eks-spelling gegee het. Die verhewe styl van die Bybel het genoodsaak dat Afrikaans met Nederlands verdeftig moes word, het die Bybelvertalers geargumenteer. Na twaalf jaar (in 1930) is die spelling van die Bybel so ver as moontlik in ooreenstemming gebring met die rigting wat AWS4 aangedui het, soos die 1933-Bybel se spelling van twede, teenoor die Nederlandse spelling tweede, en is die Bybel se drukproewe gereed gemaak. Die Bybelvertalers het genoeg gehad van ingrepe in hulle Bybelafrikaans, en die uitkomste van die gekibbel op laaste konferensies het by hulle verbygegaan.

Die Akademie en die TK was onseker oor die setel van die gesag by die spel van Afrikaans en as daar woelinge op die taalfront was, was hulle besonder gevoelig wanneer daar gedagtes uitgespreek is dat die spelling van Afrikaans deur die staat oorgeneem kan word. Onder die Paktregering is 'n vertaalkantoor ingestel waardeur Afrikaans se funksies uitgebrei is, en die 'verknoeiing van Afrikaans' (TWK 8[2] 1929:119) in amptelike stukke hokgeslaan is. Daarmee het die Staatsvertaler ook 'n sê gekry oor die Afrikaans van skoolboeke, 'n funksie wat 'n Akademiekommissie vroeër vervul het. Die Volkstem (wat Smith simpatiek gesind was) het in 1930 die Staatsvertaler se gesag betreur (Steyn 2017:119), wat aangedui het dat hy 'n nuwe onafhanklike rolspeler in die konflik tussen die WAT en die TK geword het. Dit kan ook afgelei word uit wat Bosman later daaroor geskryf het. Hy het gepraat van die verskille 'tussen prof. Smith, waarmee nou ook die Staatsvertaler gemoeid was, en die Akademie' (Bosman 1959:120). Die Akademie en die TK het jaloers daaroor gewaak dat die reglementering van Afrikaans by hulle bly setel. Die gesagskwessie? Le Roux en ander Akademielede het al van vroeg af verkondig dat die gesag van die spelling van Afrikaans by die Akademie lê, en dat 'die Akademie die hoogste ... taalliggaam' is (vgl. Le Roux 1926:271). Daar het nie gronde bestaan waarvolgens Le Roux dié uitspraak kon gemaak het nie.

Daar was talle faktore wat in die AWS4-TK se guns getel het met die uitvoer van hulle verafrikaansingsprogram, en anders as wat die TK van AWS3 ervaar het, het hulle die politieke klimaat ook tot hulle voordeel gehad. Maar desnieteenstaande alles wat in AWS4 se guns getel het, blyk dit agterna dat hulle nie hulle verafrikaansingsplanne kon vergestalt het nie.

Hoekom het nuwe reglementeringplanne dit so moeilik gemaak om ou terreine te verower? Ponelis (1999:24) merk op dat Afrikaans se standaardiseringsgeskiedenis aantoon hoe hard 'daar ... geveg moes word teen sowel Engelse jingoïsme as Nederlandse chauvinisme om Afrikaans as kultuurtaal gevestig te kry'. Dan eers kan hy bevry word van sy kombuistaalstaalstatus. Vooroordele en statusbewustheid speel 'n groot rol by taaluitbreiding.

\section{Die vonk in die kruitvat}

Al die opgehoopte frustrasies van die TK van AWS4 oor struikelblokke wat met hulle verafrikaansingsplanne opgeduik het, wat ook die redakteur van die WAT (Smith) se volgehoue ontevredenheid met die Akademie en die $A W S^{\prime} \mathrm{e}$ insluit, omdat hy hulle nie kon oorreed om die manier te volg waarop hy Afrikaans wou spel nie, het breekpunt bereik na die verskyning van ' $n$ brief in die pers wat deur die staat se hoofvertaler, mnr. J.D. Louw, geskryf is en waaraan Smith aandadig was (Odendaal 2012:344). Dit was as 'n 'rondskrywe' (omsendbrief) bedoel, wat sonder die skrywer se medewete openbaar gemaak is, en 'n 'hele opskudding' in die pers veroorsaak het (TWK 9[2] Des 1930:85). Daarvolgens sou die staat se taalkantoor ook besluitnemingsgesag oor Afrikaanse spellingsake hê. Die Akademie het onmiddellik tot die twis toegetree.

Die Akademieraad het eintlik op te veel fronte versoenend probeer optree. Dit was vir hom alreeds uiters moeilik om AWS4 se verafrikaansing te verdedig, omdat hy uit Akademiegeledere nie heelhartige ondersteuning daarvoor gehad het nie. Hoe kon die Akademie die WAT en sy redakteur Smith, die Bybelvertalers, die staat se taalinstansies, Preller en die joernaliste en skrywers in die noorde op wie hy 'n groot invloed uitgeoefen het, die uitgewers, en die Nederlandsgesindes in statusstrukture, ook in die Akademie, beweeg om hulle te versoen met die AWS se visie oor 'n skryftaal wat op Afrikaans gefundeer is? Dit was glad nie moontlik nie.

Onder hierdie omstandighede kon die belanghebbendes hulle gereed maak vir 'n spellinguitval van groot omvang.

Om tyd te wen, het die Akademie besluit om die TK se inhandiging van die manuskrip van die nuwe Woordelys te laat terughou (notule in TWK 9[1] Okt 1930:53-54). Daarnaas het hy ternouernood ' $n$ telegram aan die Minister van Onderwys, D.F. Malan gestuur, waarin hy sy dilemma uiteengesit het (AREA, Akademieargief, Raadsnotule 02/08/1930). Malan sou dalk eerder by 'n oplossing kon uitkom.

Malan, wat in 1948 Eerste Minister van Suid-Afrika sou word, se reaksie was om 'n konferensie, wat later bekend gestaan het as die Eerste Spellingkonferensie, vir 27-28 Augustus 
1930 in Pretoria te reël. Die Akademie het D.B. Bosman en S.P.E. Boshoff as hulle verteenwoordigers by die voorgestelde samespreking benoem. Malherbe en Le Roux was nie daarby betrokke nie.

\section{Hoe die konferensie verloop het}

Sou hierdie Konferensie die TK van AWS4 se verafrikaansingspoging darem waardeer? Die ordereëls vir die konferensie was insiggewend. Die sekretaris van Onderwys dr. S.F.N. Gie, het daarop gewys dat die Konferensie geen bindende krag het nie. Niemand kon hulle dus op enige gesag beroep het om die spellingkwessie op te los nie. Die konferensie kon daarom nie 'n afdwingbare besluit neem nie, en Malan het dit benadruk dat onderlinge verskille nie deur stemming opgelos gaan word nie. Die konferensiegangers moes daarna streef om eenstemmigheid na gesprekvoering te bereik.

Dit is onwaarskynlik dat oorredingsgesprekke met Smith die gewenste uitwerking sou hê. Sy teenstand teen verafrikaansing was ook ideologies begrond. Gesprekke oor onverkwiklikhede tussen hom en die res van die TK het teruggereik na sy vertraging van die afhandeling van die drukkersproewe van AWS1 en AWS2 al in 1916 en 1917. In beide gevalle wou Smith die drukkersproewe nie afteken nie (Akademie-argief, AREA, Korrespondensie van die Akademiesekretaris met Smith en Malherbe, Sept. 1917, telegramme Akademiesekretaris en Du Toit, Reitz, 2/10/1917). Daardie drukproses kon uiteindelik voortgaan, maar Smith het daarna steeds sy eie kop gevolg. Die TK was ook nie vatbaar vir Smith se vernederlandsingsplanne nie. Vir die beeld van Afrikaans sou verskillende spellings in toonaangewende publikasies soos die WAT en die AWS'e 'n onhoudbare situasie geskep het, en daar moes naarstiglik na oplossings gesoek word.

Gie het nie net melding gemaak van die groot kulturele waarde wat 'n eenvormige Afrikaans vir sy sprekers inhou nie, maar hy het ook op die beduidende finansiële waarde gewys wat aan gestandaardiseerde Afrikaans gekoppel is. Gemeet teen die dokumente wat voorberei is om dié kwessie te verduidelik, was hierdie saak nogal belangrik. Gie het briewe voorgelees van die uitgewersfirma J.L. van Schaik en A.K. Bot, een van die samestellers van die Eerste Afrikaanse skoolatlas, waarin húlle belange by 'n eenvormige reglementering van Afrikaans verduidelik is. W.J. Viljoen van die Taalbond, het in 1925 ook verwys na die inkomste wat hy moes prysgee toe die Nederlandstalige skoolboeke waarby hy betrokke was, vervang is deur Afrikaanse onderrigmateriaal (Kannemeyer 1995:452). Die terreinuitbreiding wat gepaard gegaan het met Afrikaans se standaardisering vanaf die onderkant van die sosiale leer, is meermale in die dagblaaie as aanhoudende vitterigheid oor spellingongedurigheid vermeld. Het dit nie dalk die indruk van onvastheid geskep, wat nie goed was vir die handelsomgewing wat om gereglementeerde Afrikaans ontwikkel het nie? 'n Gevestigde taal soos Nederlands, daarenteen, stal nie so 'n rondspringery oor spellingsake uit nie. Moet die verafrikaansingsgedagte nie maar met die oog op groter taalekonomiese stabiliteit tersyde gestel word nie?

Malan het die Konferensiegesprekke ook tot die spelling van vreemde woorde en eiename beperk. Met hierdie beperking het hy eintlik bedoel dat die vergadering moes kyk na waar AWS4 se TK te ver gegaan het met hulle verafrikaansingsprogram, en waar hulle te veel Nederlandse woorde wat hulle as vreemde woorde beskou het, geskrap het.

Hoe objektief het Malan, 'n oud-Stellenboscher, wat aandadig was aan die vestiging van die WAT in Stellenbosch, en nie by die Akademie nie (Kapp 2009; Steyn 2014:214), gestaan in hierdie aanslag teen die verafrikaansing van AWS4? Hoe positief kon hy geoordeel het oor die Akademie se kuratorskap van Afrikaans? Vir Langenhoven was Malan 'te hopeloos pro-Hollander' (Kannemeyer 1995:344), en was hy traag om vir Afrikaans teen Nederlands kant te kies, het Langenhoven in 'n toespraak op 22 Februarie 1918 op Oudtshoorn gesê. Langenhoven het De Burger waarvan Malan redakteur was, van 'n pro-Hollandse gesindheid beskuldig omdat dié koerant Nederlands se offisiële funksie te lank probeer behou het, en onder meer die lidwoord $D e$ in die koerantnaam De Burger nie as 'n vreemde woord vir Afrikaanssprekendes gesien het nie.

Verder was Langenhoven ook ontevrede omdat politieke toesprake wat in Afrikaans gelewer is, in Malan se koerant in Nederlands gerapporteer is (Kannemeyer 1995:410). De Burger het eers in 1922, twee jaar voor die Paktregering aan bewind gekom het, en waarin Malan toe minister geword het, oorgegaan na Die Burger toe. Smith was van 1916 af mede-redakteur van De Huisgenoot en dié tydskrif het reeds in 1917 Die Huisgenoot geword (Steyn 2014:166).

Die TK van AWS4 het 'n kategorie Afrikaanse woorde geïdentifiseer wat sonder Nederlandse teenhangers opgeneem is. Die Konferensie het hierdie indeling nie daar gelaat nie, en Nederlandse wisselvorme bygevoeg. In die Voorwoord van AWS4 is taamlik sarkasties in 'n verhulde lofprysing op hierdie ingreep gereageer. Op grond van die 'leiding en bemoeiinge' van die Akademie, staan daar, het AWS4 se TK aangeneem dat die spelling van 'suiwer Afrikaanse woorde nou as vrywel vasstaande beskou word' (AWS4:IV). Dit wil sê dat dié woorde sonder Nederlandse wisselvorme kon bestaan. 'Al was dit die enigste wat die Akademie tot stand gebring het, dan was sy bestaan hierdeur reeds geregverdig', het die opmerking verder gelui.

Na afloop van die konferensie moes die TK van AWS4 inskrywings wat $A W S 3$ al geskrap het, wéér opneem. Woorde wat volgens die Afrikaanse skryfwyse met ou- gespel is, kon nou ook met au-gespel word soos in Nederlands, byvoorbeeld outomaties of automaties. Die $x$-spelling is ook toegelaat naas 
die Afrikaanse $k s$-spelling, wat die Bybelvertalers goed gepas het. Hulle skryfwyse van Exodus, byvoorbeeld wat die konferensie naas Eksodus aanvaarbaar gevind het, is nog nie voorheen deur TK's erken nie (vgl. ook Bosman 1959:121). Uit die voorwoord blyk dit dat AWS4 daar anders sou uitgesien het as die Spellingkonferensie van 1930 nie ingegryp het met die TK se werk nie.

'Kompromisse beteken altyd die verlogening van beginsels, ook van spellingbeginsels' is die versigtige verwyt van AWS4 se TK aan die Konferensie in sy Voorwoord. Die kompromieë het beteken dat AWS4 (1921-1931) se verafrikaansingsplanne nie tot die opstellers se bevrediging uitgevoer kon word voordat die manuskrip na die drukkers toe is nie. Die TK van AWS4 is in sy spore gestuit, en moes selfs omdraai om van hulle vorige besluite te hersien. Odendaal (2016:271) vestig die aandag op heelwat gevalle waar verafrikaansings verwag kon word, en wat die TK van AWS4 nie deurgevoer het nie, waaronder affidavit, autochthoon, demon, detachement, fok (teel), gesusters, interrogasie, kasueel, keuken, konfessie, konfirmasie, malisieus, mediateur en moedervlek.

$\mathrm{Na}$ afloop van die vergadering was dit duidelik dat die Eerste Spellingkonferensie 'n meer konserwatiewe Nederlandse beeld van Afrikaans voorgestaan het (vgl. ook Odendaal 2016:270 hieroor). Die verafrikaansingsplanne van die AWS4-TK is nie waardeer nie. Die Redakteur van die WAT (Smith) is nie erg deur die besluite van die vergadering geraak nie. Hy is wel versoek om die skryfwyse van die kategorie Afrikaanse woorde van AWS4, nadat die vergadering dit uitgedun het, te eerbiedig. Die AWS4-TK, daarenteen, moes heelwat sigbare toegewings maak aan die Nederlandssimpatieke spellingvoorstelle wat die Smith-groepering ter tafel gebring het (vgl. ook Malan 1974:292).

'n Verslag van die Spellingkonferensie is op 20 September vir goedkeuring aan die Minister gestuur en dit het op 27 September in die pers verskyn (TWK 9[2], Des 1930:85-89).

Dalk het die AWS4-TK die vrede nie vertrou nie, en het hulle dit erns gemaak met die finalisering van hulle manuskrip, in ooreenstemming met die finale gedagtes van die Konferensie. In Desember 1930, vier maande na afloop van die Pretoriakonferensie, was die AWS4-manuskrip persklaar. In 1931 het AWS4 verskyn. Miskien die enigste AWS waarby sy TK moes toekyk hoe ander deelnemers sy inhoud bepaal. In sy Voorwoord vind ' $n$ heerlike spel van innuedo's en sinspelings plaas met dié gebeure in die oog.

\section{Die koningsvrede}

Die Konferensie het ooreengekom dat die spelling van AWS4 vir 'n oorgangstydperk van twee jaar na 01 Oktober 1930 geldig sal bly. Die toegewing het dit moontlik gemaak dat die AWS4-TK die laaste maande van 1930 kon gebruik om hulle werk aan die afhandeling van AWS4 sonder verdere inmenging uit te voer.

\section{Naskrif}

Die verhaal van AWS4 moes met sy publikasie in 1931 geëindig het. Dit was egter nie die geval nie. Die spellingvrede van twee jaar het op die oppervlakte 'n vals beeld geskep - 'n beeld van rustige konsolidasie en van spellingverskille wat dalk in die toekoms vergeet gaan word.

Op die spellingterrein was daar egter nie vrede nie. 'n Teken daarvan was dat senator F.S. Malan wat op hoogte gebly het van voortdurende spellingonverkwiklikhede, op 06 Junie 1931 in die Parlement vir'n versoening tussen die steeds strydende partye gevra het. Die Eerste Spellingkonferensie het nie in sy doel geslaag nie. Die Akademie wou Malan se versoek opvolg, en wou die hoeveelste versoeningsgesprek tussen die ontevredenes inisieer. Twee lede van die TK, twee van die geswore 'verafrikaansers', Malherbe en Boshoff, het 'so 'n gesprek as 'n toegewing aan Smith beskou', en het geweier om aan daardie Akademie-geïnisieerde diskussie deel te neem (AREA, Akademieargief, Malherbekorrespondensie 16 Oktober 1931). Het Malherbe en Boshoff die Akademie van bevooroordeeldheid teen die TK van AWS5 verdink? Dit lyk so. Politiek kon ook 'n rol in hulle optrede gespeel het. Standaardisering raak baie kante. Beide Malan en Smith was toe as Verenigde Party-ondersteuners bekend. Malherbe het in 1959 onthou 'dat sinistere inmenging van die politiek goed bedoelde werk tot stilstand moes dwing' (Malherbe 1959:40).

Die opponente van die verafrikaansingsgedagte in die $A W S^{\prime} \mathrm{e}$ het kragte gemonster vir 'n tweede, sterker aanslag wat hulle geloods het op die Tweede Spellingkonferensie wat van 4 tot 6 Januarie 1932 op Stellenbosch gereël is. Weer eens het dit gegaan oor die 'geskil tussen ons en die Smith rigting' (Malherbe 1959:43), hoewel die Staatsvertaler weer betrek is, en steeds het dit om die spelling van 'vreemde woorde' (Nederlandse woorde) gegaan. Die Konferensie het 'ons spellingbeleid ' $n$ lang tyd vertraag', herinner Malherbe hom daardie omstandighede. Met daardie spellingbeleid het Malherbe die TK's se verafrikaansingsprogram van die AWS'e na 1918 in gedagte gehad.

Gelukkig was AWS4 toe alreeds gepubliseer.

D.F. Malan het hierdie konferensie ook laat reël, in 'n stadium toe sy ministerskap einde se kant toe gestaan het. Hofmeyr het ná hom in 'n koalisiekabinet Minister van Onderwys geword. Hofmeyr het nie verbintenisse met Smith en die WAT gehad nie, en ook nie met die TK nie. Na afloop van die Konferensie het hy op sy manier die kastaiings uit die vuur gekrap.

\section{Die 1932-besluit}

Wie sou die besluit kon voorsien wat die 1932spellingkonferensie geneem het? Dit was 'n besluit wat die opstellers van AWS4 soos 'n voorhamerslag getref het. Verafrikaansing was steeds nie algemeen aanvaarbaar nie. Die konferensiegangers het in 1932 ooreengekom om wysigings aan te bring aan die besluite wat alreeds in 1930 in 
AWS4 gepubliseer is. Hierdie regstellings is genotuleer vir die aandag van die samestellers van AWS5 (1931-1937), omdat AWS4 alreeds flink aan die verkoop was (AWS5:III). D.B. Bosman (vgl. Bosman 1932) is versoek om die besluite van die 1932-spellingkonferensie in ' $n$ verslag saam te vat, wat die Akademie gepubliseer het. (Vgl. McLachlan 2016 vir 'n bespreking van party van die veranderings.)

Woordelysgebruikers is versoek om hierdie wysigings in hulle eksemplare van AWS4 aan te bring. Hoeveel van hulle sou aan dié versoek gehoor kon gegee het? AWS4 is daarna onder uiters onbevredigende omstandighede gebruik.

\section{Implikasies van die 1932-besluit}

Die sekretaris van Onderwys, S.F.N. Gie, het as voorsitter opgetree, en het die uitkoms van hierdie konferensie amptelik, op aandrang van die Akademie, op 15 September 1932 as 'n vasstaande besluit (waarskynlik van die Departement van Onderwys) geproklameer (Korrespondensie tussen Akademiesekretaris en S.N.F. Gie, 10/08/1932, Akademieargief, AREA). Die Akademie was veral gretig dat die besluit wat die WAT ook geraak het, moes vasstaan: Die hoofredakteur van die WAT moes genoeë neem met die Taalkommissiespelling, het die proklamasie gelui. Die Akademie se gesag oor dié belangrike publikasie waarvan Smith hoofredakteur was, is deur hierdie proklamasie bevestig.

Die gesag van die Akademie oor spellingsake is op nog 'n manier bevestig toe Hofmeyr, die nuwe Minister van Onderwys, in 1933 opdrag aan die Staatsdrukker gegee het om die Akademiespelling te volg. Dit het eenvormigheid beteken, en hieroor was uitgewers hoog in hulle skik (Steyn 2014:215). By wisselvorme moes die betrokkenes verder, in geval van onduidelikheid, die verafrikaanste vorm kies. Dit was vir die staat se Taalkantoor 'n aanduiding dat hy ook nie self spellingbesluite kon neem nie. Moontlik het Hofmeyr se beslissing ook beteken dat hy nie verder met hierdie huismoles oor die standaardisering van Afrikaans gepla wil wees nie.

Vir die volgende ses jaar, totdat AWS5 in 1937 verskyn het, was daar nie algemene sekerheid oor die Afrikaanse spelling nie. S.I. Malan (1963:209) praat tereg van die 'verwarring oor die Afrikaanse ortografie' wat toe geheers het. Eintlik was die situasie erger: daar was vir hierdie tydperk nie duidelike riglyne oor die spelling van Afrikaans nie.

Die 1932-wysigings aan AWS4 (Bosman 1932) sou 'n invloed op die Bybelspelling gehad het, maar die wysigings was te laat vir die Bybelvertalers (vgl. Venter 1964:166). Na die ingrype van die tweede spellingkonferesie was daar spellings wat met die Bybelse verskyning al as verouderd geëtiketteer is, byvoorbeeld i/ie-spellings, en die -ee- in afleidings van woorde met -ee- in oop lettergrepe, soos die spelling tweede. Die Tweede Spellingkonferensie het die spelling twede van AWS4 ongeldig verklaar (vgl. Genesis 1:8
'... en dit was môre, die twede dag' volgens 'n spelreël wat toe nie meer bindend was nie). Ironies het die Voorwoord van AWS4 (1931:V) juis verwys na die Afrikaanse Bybelvertaling wat die gebruik van 'die bestaande spellingtradisie verder [sal] bestendig'. Dit was na al die ingrepe van buite nie meer die geval nie.

\section{Slot}

Dit staan geensins vas dat dit vir Afrikaans voordeliger is om op 'n Afrikaanse manier gespel te word nie. Ander TK's kon Afrikaans baie maklik anders gespel het. Maar die verafrikaansers het die stryd gewen, wat veral van AWS3 af aan Le Roux en Malherbe toegeskryf kan word, trouens die hele TK van AWS4-faam, se verafrikaansingspoging kan nie vergeet word nie. Hulle was net tydelik in hulle spore gestuit.

\section{Erkenning}

Met erkenning aan die Suid-Afrikaanse Akademie vir Wetenskap en Kuns en die Taalkommissie wat 'n ondersoek na die geskiedenis van die AWS moontlik gemaak het.

\section{Mededingende belange}

Die outeur verklaar hiermee dat hy geen finansiële of persoonlike verbintenis het met enige party wat hom voordelig of nadelig kon beïnloed het in die skryf van hierdie artikel nie.

\section{Literatuurverwysings}

Akademie vir Wetenskap en Kuns, 1910 tot 1922, Jaarboek 1 tot 12.

Belcher, R., 1987, 'Afrikaans en kommunikasie oor die kleurgrens', in H. du Plessis \& T. du Plessis (reds.), Afrikaans en taalpolitiek, bl. 17-36, HAUM, Pretoria.

Boshoff, S.P.E., 1921, Volk en taal van Suid-Afrika, De Bussy, Pretoria.

Boshoff, S.P.E., Bosman, D.B., Le Roux, T.H. \& Malherbe, D.F., 1931, 'In opdrag van die Suid-Afrikaanse Akademie vir Taal, Lettere en Kuns', in Afrikaanse woordelys en spelreëls [AWS4], 4e uitg., Nasionale Pers, Bloemfontein.

Boshoff, S.P.E., Bosman, D.B., Hiemstra, L.W., le Roux, T.H. \& Malherbe, D.F., 1937, 'In opdrag van die Suid-Afrikaanse Akademie vir Taal, Lettere en Kuns', in Afrikaanse woordelys en spelreëls [AWS5], 5e uitg., Nasionale Pers, Bloemfontein.

Bosman, D.B., Le Roux, T.H., Malherbe, D.F. \& Smith, J.J., 1921, 'In opdrag van die Suidafrikaanse Akademie vir Taal, Lettere en Kuns', in Afrikaanse woordelys en spelreëls [AWS3], 3e uitg., Die Nasionale Pers, Bloemfontein.

Bosman, D.B., 1932, Lys van wysigings wat ingevolge die besluite van die Spellingkonferensie op Stellenbosch Januarie 1932, moet aangebring word in die Afrikaanse Woordelys en Spelreëls (4 de druk) van die S. A. Akademie vir Taal, Lettere en Kuns, Nasionale Pers, Kaapstad.

Bosman, F.C.L., 1959, 'Geskiedkundige oorsig van die Suid-Afrikaanse Akademie vir Wetenskap en Kuns', in T.E.W. Schuman et al (reds.), Feesalbum 1909-1959, bl. 73-166, Suid-Afrikaanse Akademie vir Wetenskap \& Kuns, Pretoria.

Brink, L.E., 2015, Die lewe, werk en invloed van F.V. Engelenburg in Suid-Afrika (18891938), Ongepubliseerde proefskrif, Noordwes-Universiteit, Vaaldriehoekkampus.

Davids, A., 2011, The Afrikaans of the Cape Muslims, H. Willemse \& S.E. Dangor (reds.), Protea Boekhuis, Pretoria.

De Klerk, G.J., 1994, 'Die taalgebruik en spellingvorme van 'n riemlandse Afrikaner tydens die eeuwending' in G. Olivier \& A. Coetzee (reds.) Nuwe perspektiewe op die geskiedenis van Afrikaans, bl. 180-194, Southern Boekuitgewers, Halfweghuis.

Die Burger, 1930, 'Titel onbeskikbaar', Die Burger, 25 Oktober, n.p.

Du Plessis, H., 2001, 'Die ontwikkeling van die Afrikaanse variasietaalkunde', in A. Carstens \& H.P. Grebe (reds.), Taallandskap, bl. 69-80, Van Schaik, Pretoria.

Du Toit, S.J., 1880, 'herdruk in 1909', in Geskidenis fan di Afrikaanse Taalbeweging uit publike en prifate bronne: Bewerk deur 'n Lid fan di Genootskap fan Regte Afrikaners, Paarl Drukpers, Paarl.

Du Toit, S.J., 1897, Fergelijkende Taalkunde fan Afrikaans en Engels, D.F. du Toit \& Paarl Drukpers, Paarl.

Eksteen, L.C., 1985, 'Die rol van die Akademie in die standaardisering van die Afrikaanse spelling', Stellenbosch Papers in Linguistics Plus 10, 169-200. 
Elffers, H. \& Viljoen, W.J., 1908, Beknopt Nederlands Woordeboek voor Zuid-Afrika, Juta, Kaapstad.

Giliomee, H., 2009, The Afrikaners, Tafelberg, Cape Town.

Kallaway, P., 1974, 'F.S. Malan, the Cape liberal tradition, and South African politics 1908-1924', The Journal of African History 15(1), 113-129. https://doi. org/10.1017/S002185370001327X

Kannemeyer, J.C., 1995, Langenhoven: 'n Lewe, Kaapstad, Tafelberg.

Kapp, P., 2009, Draer van 'n droom: Die geskiedenis van die Suid-Afrikaanse Akademie vir Wetenskap en Kuns 1909-2009, Hemel en see boeke, Hermanus.

Le Roux, T.H., Malherbe, D.F. \& Smith, J.J., 1917, 'In opdrag van die Suidafrikaanse Akademie vir Taal, Lettere en Kuns', in Afrikaanse woordelijs en spelreëls [AWS1] 1e uitg., Het Volksblad-Drukkerij, Bloemfontein.

Le Roux, T.H., Malherbe, D.F. \& Smith, J.J., 1918, 'In opdrag van die Suidafrikaanse Akademie vir Taal, Lettere en Kuns', in Afrikaanse woordelijs en spelreëls [AWS2] 2e uitg., De Nationale Pers, Bloemfontein.

Le Roux, T.H., 1926, 'Die geskiedenis van die Afrikaanse spelling', in Gedenkboek ter eere van die Genootskap van Regte Afrikaner, Die Weste-Drukkery, Potchefstroom.

Le Roux, T.H., 1968a, 'Die geskiedenis van die Afrikaanse spelling', in P.d.V. Pienaar (red.), Kultuurgeskiedenis van die Afrikaner, bl. 163-174, Nasionale Boekhandel, Kaapstad.

Le Roux, T.H., 1968b, 'Die spraakmakende gemeente', in T.H. le Roux (red.), Afrikaanse Taalstudies, ${ }^{11}$ bl. 142-148, Van Schaik, Pretoria.

Liebenberg, B.J., 1968, 'Van die statuut van Westminister tot die Republiek van Suid Afrika, 1931-1961', in C.F.J. Muller (red.), 500 jaar Suid-Afrikaanse geskiedenis, bl. 371-401, Academica, Pretoria.

Malan, S.I., 1963, Die spelling van Afrikaans, DLitt-proefskrif, UOVS, Bloemfontein.

Malan, S.I., 1974, 'Die groei van Afrikaans as skryftaal', in B. Kok (red.), Afrikaans: Ons pêrel van groot waarde, bl. 279-293, Federasie van Afrikaanse Kultuurvereniginge, Johannesburg.

Malherbe, D.F., 1959, Herinneringe in verband met die Akademie. In, Die SuidAfrikaanse Akademie vir Wetenskap en Kuns, Feesalbum 1909-1959, bl. 40-43, Van Schaik, Pretoria.

Mansveldt, N., 1884, Proeven van een Kaapsch-Hollandsch idioticon, met toelichtingen en opmerkingen betreffende land, volk en taal, Van de Sandt de Villiers Drukpers, Kaapstad.

McLachlan, J.D., 2016, 'Standaardafrikaans, standaardspelling en die AWS', Tydskrif vir Geesteswetenskappe 56 (2-1), 477-502.

Nienaber, G.S., 1940, Klaas Waarzegger se Zamenspraak en Brieve uit 1861, Voortrekkerpers, Johannesburg.

Nienaber, G.S., 1968, Louis Henri Meurant: 'n Vroeë Afrikaanse joernalis, Nasionale Boekhandel, Kaapstad.

Odendaal, B.G., 2012, 'Die herstandaardisering van Afrikaans: 'n Praktiese benadering met die AWS as gevallestudie', Proefskrif vir die graad Doktor in die Wysbegeerte aan die Universiteit van Stellenbosch.
Odendaal, G., 2016, 'Die rol van die US se Departement Afrikaans en Nederlands in die ontwikkeling van die Afrikaanse leksikografie: Die Nederlands-Afrikaans-stryd gedurende die aanvangsjare', Tydskrif vir Geesteswetskappe 56(1), 257-281. gedurende die aanvangsjare', Tydskrif vir Geesteswets
https://doi.org/10.17159/2224-7912/2016/v56n1a16

Ponelis, F., 1999, 'Die oorspronge van Afrikaans', Ongepubliseerde voordrag, Klein Karoo Nasionale Kunstefees.

Raidt, E.H., 1986, 'Taalvariasie in agtiende-eeuse vrouetaal', SA Tydskrif vir Taalkunde 4(4), 101-145. https://doi.org/10.1080/10118063.1986.9724234

Steyn, J.C., 1987, Trouwe Afrikaners, Tafelberg, Kaapstad.

Steyn, J.C. 2014, Ons gaan 'n taal maak: Afrikaans sedert die Patriot-jare, Kraal uitgewers, Centurion.

Steyn, J.C., 2015a, Afrikaners in die branding: N P van Wyk Louw se 'Kultuur en krises' vandag, FAK, Pretoria.

Steyn, R., 2015b, Jan Smuts: Unafraid of greatness, Jonathan Ball, Johannesburg.

Steyn, J.C., 2017, 'Die laaste projek van die "Hollandse taalbeweging in Suid-Afrika": die Vereenvoudigde Hollandse Spelling', Tydskrif vir Geesteswetenskappe 57(2-1), 233-248.

Taalkommissie (samest.), 1964, 'In opdrag van die Suid-Afrikaanse Akademie vir Wetenskap en Kuns', in Afrikaanse woordelys en spelreëls [AWS7], 7e uit. Tafelberg-, Kaapstad.

Taalkommissie (samest.), 1991, lin opdrag van die Suid-Afrikaanse Akademie vir Wetenskap en Kuns', in Afrikaanse woordelys en spelreëls [AWS8], 8e uitg.,Tafelberg, Kaapstad.

Taalkommissie (samest.), 2002, 'In opdrag van die Suid-Afrikaanse Akademie vir Wetenskap en Kuns', in Afrikaanse woordelys en spelreëls [AWS9], 9e uitg., Pharos, Kaapstad.

Taalkommissie (samest.), 2017, 'In opdrag van die Suid-Afrikaanse Akademie vir Wetenskap en Kuns', in Afrikaanse woordelys en spelreëls [AWS11], 11e uitg. Pharos, Kaapstad.

Tydskrif vir Wetenskap en Kuns (TWK), 1922-Februarie 1939, Vereniging vir Wetenskap en Kuns, Pretoria.

Uys, M.D., 1983, 'Die Vernederlandsing van Afrikaans', (Ongepubliseerde proefskrif) Universiteit van Pretoria, Pretoria.

Van Rensburg, C., 2017a, 'Na honderd jaar: Die Afrikaans van die eerste taalkommissie', Tydskrif vir Geesteswetenskappe 57(2), 249-270.

Van Rensburg, C., 2017b, 'Die totstandkoming van die eerste Afrikaanse Woordelys en Spelreëls', in Suid-Afrikaanse Akademie vir Wetenskap en Kuns, Faksimilee-uitgawe van Afrikaanse Woordelys en Spelreëls 1, bl. 1-22, Protea Boekhuis, Pretoria.

Van Rensburg, C., 2017c, 'Die slag toe slim sy baas gevang het', Stellenbosch Papers in Linguistics 48, 51-66.

Van Rensburg, M.C.J. \& Combrink, J.G.H., 1984, 'Transvaalse Afrikaans', in T.J.R. Both (red.), Inleiding tot die Afrikaanse taalkunde, bl. 107-133, Academica, Pretoria.

Van Rijn, C.J., 1908, Dutch-English and English-Dutch dictionary in the new spelling, G.B. van Goor, Gouda.

Venter, H., 1964, 'Die Afrikaanse spelling', in H.J.J.M. van der Merwe (red.), Studierigtings in die taalkunde, bl. 156-174, Van Schaik, Pretoria. 